he rightly places equivalent emphasis on dissecting how and why wealthy countries and their leaders should take action and comply with his recommendations, such as cancelling debt. While the world's most powerful nations have repeatedly committed to contributing $0.7 \%$ of GNP to development aid, disinformation persists to exaggerate perceptions of current levels of assistance (which are actually below $0.2 \%$ in the US and below $0.4 \%$ in Canada), and public support for increasing assistance is muted in the belief that misspent funds are not producing results.

In his role as an impassioned advo- cate for challenging global poverty, something that earns rock star Bono's glowing foreword to this book, Sachs, who now heads Columbia University's Earth Institute, systematically picks apart the standard arguments of defenders of the status quo. For example, while acknowledging that corruption and poor governance in low-income countries must be overcome if aid is to be effective, he exposes the frustrations faced by relatively well-governed countries such as Ghana, who despite their well-reasoned national strategies are still stonewalled by a lack of international agency support. The tragedy of HIV/AIDS emerged, after

\title{
Reading
}

\section{A marvellous invention}

On the second of his improbable travels, Lemuel Gulliver is blown off course to Brobdingnag, where he finds himself much diminished. By Gulliver's scale the people are gargantuan, but their understanding is small. Their education consists of mere "Morality, History, Poetry and [applied] Mathematicks. "Abstraction is unknown; no law is more than twenty-two words long. A vast militia lies fallow, constrained by the discipline of peace. A narrow outlook affects even the King, who has no appreciation for the glories of war. - CMAJ

... In hopes to ingratiate my self farther into his Majesty's Favour, I told him of an Invention discovered between three and four hundred Years ago, to make a certain Powder; into an heap of which the smallest Spark of Fire falling, would kind the whole in a Moment, although it were as big as a Mountain; and make it all fly up in the Air together, with a Noise and Agitation greater than Thunder. ... That we often put this Powder into large hollow Balls of Iron, and discharged them by an Engine into some City we were besieging; which would rip up the Pavement, tear the Houses to Pieces, burst and throw Splinters on every Side, dashing out the Brains of all who came near. That I knew the Ingredients very well, which were Cheap, and common; I understood the Manner of compounding them, and could direct his Workmen how to make those Tubes of a Size proportionable to ... batter down the Walls of the strongest Town in his Dominions in a few Hours; or destroy the whole Metropolis, if ever it should pretend to dispute his absolute Commands. Thus I humbly offered to his Majesty, as a small Tribute ...

The King was struck with Horror at the Description I had given of those terrible Engines, and the Proposal I had made. He was amazed how so impotent and groveling an Insect as I (these were his Expressions) could entertain such inhuman Ideas, and in so familar a Manner as to appear wholly unmoved at all the Scenes of Blood and Desolation which I had painted as the common Effects of those destructive Machines ... . As for himself, he protested, that although few Things delighted him so much as new Discoveries in Art or in Nature; yet he would rather lose Half his Kingdom than be privy to such a Secret; which he commanded me, as I valued my Life, never to mention any more.

From Swift J. A voyage to Brobdingnag, ch. 6. Gulliver's Travels. Dublin: 1727.

all, in circumstances where health budgets in most countries in sub-Saharan Africa were dwarfed by debt repayment obligations to wealthy countries (a sharp contrast to how the US had provided assistance for post-World War II reconstruction through the Marshall Plan, as is pointedly presented).

The systematic failure of wealthy countries to live up to their promises may ultimately remain the most fundamental weakness of the manifesto that Sachs has developed. It is difficult to have faith in the feasibility of the world's powerful suddenly taking up his prescriptions when these same countries so disappointingly moved away from facing up to their accountability for eradicating poverty and meeting Millennium Development Goals at the UN's Summit and the G8 meeting in 2005. Sachs spends little time considering how other global forces may be required to pressure a shift in policy, as was witnessed at the round of international trade talks in Cancun when low- and middle-income countries refused to accept the agenda being promoted by the world's wealthy, such as further restrictions on international property rights. And there is nary a mention of countries such as Cuba that have defied conventional development models and provided excellent health outcomes despite weak economic growth.

Another weakness of the book is the not uncommon practice of a narrator setting himself in a positive light and avoiding self-critical assessments. In claiming victory for the successful conquering of hyperinflation in Bolivia, for example, Sachs treads lightly on the severe structural problems of poverty that persist, often aggravated by the privatization that his policy recommendations promoted.

Despite its limitations, The End of Poverty makes a formidable contribution to our understanding of the disparities that ravage our 2Ist-century world, and a reminder that the potential for change exists if we can muster the necessary political will. The extreme poor need not always be with us after all.

\section{Jerry M. Spiegel}

Director, Global Health

Liu Institute for Global Issues

University of British Columbia

Vancouver, BC 